\title{
Comparison of Four Methods for DNA Extraction From Echinococcus granulosus Protoscoleces
}

\section{Echinococcus granulosus Protoskolekslerden DNA İzolasyonu İçin Dört Farklı Yöntemin}

\section{Karşılaştırılması}

\author{
Khosrow Hazrati Tappeh1, Haleh Hanifian², Kambiz Diba² \\ ${ }^{1}$ Cellular and Molecular research Center, Urmia University of Medical Sciences, Urmia, Iran \\ ${ }^{2}$ Department of Parasitology and Mycology, Faculty of Medicine, Urmia University of Medical Sciences, Urmia, Iran
}

\section{ABSTRACT}

Objective: Cystic echinococcosis caused by the dog tapeworm Echinococcus granulosus, is a global zoonotic infection which is economically important and constitutes a major threat to public health in many countries, especially in Middle Eastern countries. Strain characterization is essential for the establishment of a preventive and control strategy in every endemic area. Before all molecular studies, it is necessary to achieve DNA of the parasite. The aim of this study was to compare four simple methods of DNA extraction from protoscolecses of E. granulosus in samples from the West Azerbaijan province of Iran.

Methods: After collecting sheep and cow hydatid cysts from several slaughterhouses of the province, DNA samples were extracted using four different methods involving the use of glass beads, commercial DNA extraction kit, boiling and crushing. For all DNA samples extracted, electrophoresis on $1.3 \%$ agarose gel was performed.

Results: The methods were compared regarding DNA, time and cost effectiveness and facility. All methods showed some advantages and disadvantages. The commercial kit method, which was the most time and cost effectiveness method, achieved no bands and glass beads method had the best results on gel electrophoresis.

Conclusion: Glass beads and boiling methods were the most suitable methods regarding their ease, quickness and cost effectiveness. (Turkiye Parazitol Derg 2012; 36: 100-4)

Key Words: Echinococcus granulosus, DNA, Extraction methods

Received: 26.01.2012

Accepted: 04.05.2012

\section{ÖZET}

Amaç: Köpek tenyası adı da verilen Echinococcus granulosus'un sebep olduğu Kistik ekinokokkosiz, ekonomik önemi de olan ve dünya çapında görülen zoonotik bir enfeksiyondur. Başta Orta Doğu ülkeleri olmak üzere birçok ülkede halk sağlığını tehdit eden önemli bir parazitozdur. Suş karakterizasyonunun yapılması endemik alanlarda önleme ve kontrol stratejilerinin geliştirilmesinde esastır. Moleküler çalışmalar öncesinde parazit DNA'sının izolasyonu gerekli olduğu için bu çalışmada İran'ın Batı Azerbaycan ilinden elde edilen E. granulosus protoskolekslerinden DNA izolasyonu için dört farklı yöntemin karşılaştırılması amaçlanmıştır.

Yöntemler: ildeki birkaç mezbahadan koyun ve ineklerden hidatik kistlerin toplanmasından sonra, DNA örnekleri ticari DNA ekstraksiyon kiti, kaynatma, parçalama ve cam boncukların kullanımını içeren dört farklı yöntemle ekstrakte edilmiştir. Ekstrakte edilen bütün DNA örnekleri \%1.3'lük agaroz jel elektroforezinde yürütülmüştür.

Bulgular: Töntemler DNA kalitesi açısından, zaman, maliyet ve laboratuvar olanakları açısından karşılaştııılmışır. Bütün yöntemlerde bazı avantaj ve dezavantajların olduğu belirlenmiştir. En fazla zaman alan ve maliyeti yüksek olan ticari kit yöntemi ile bir bant elde edilemezken cam boncuk yönteminin elektroforezde en iyi sonucu verdiği görülmüştür.

Sonuç: Cam boncuk ve kaynatma yöntemlerinin hızlı, kolay ve maliyeti az olduğu için en uygun yöntemler olduğu belirlenmiştir. (Turkiye Parazitol Derg 2012; 36: 100-4)

Anahtar Sözcükler: Echinococcus granulosus, DNA, ekstraksiyon yöntemleri

Kabul Tarihi: 04.05.2012

Address for Correspondence / Yazışma Adresi: Dr. Khosrow Hazrati Tappeh, Department of Parasitology and Mycology, Medical Sciences, Urmia University, Urmia, Iran Phone: 00989143433134 E-mail: xhazrati@yahoo.com doi:10.5152/tpd.2012.24 


\section{INTRODUCTION}

Hydatid cyst caused by the larval stage of Echinococcus granulosus is a worldwide zoonosis. The parasite is an important health problem that causes economic loss, especially in developing countries (1) The disease is endemic in the Middle East, Central Asia and Northern and Eastern Africa (2-4). A number of genetic variants of $E$. granulosus have been described. These genetic variations may determine phenotypic characteristics, host specificity, antigenicity, transmission dynamics, infection route, pathology, control, antimicrobial susceptibility and vaccine development strategies (5).

Therefore, characterizing the exact etiological agent in different areas is necessary in order to determine transmission patterns and control programs. DNA technology has had a major role in many aspects of Parasitology, including diagnosis, epidemiology, analysis of population genetic structures and vaccine development. In particular, the polymerase chain reaction (PCR) has found broad applicability, because its sensitivity allows gene amplification from minute amounts of parasite material. This is of particular importance as it is frequently not possible to isolate adequate amounts of material from some parasites and their different life-cycle stages. Performing any DNA-based technique requires extracting DNA as the first and crucial step that can have a significant effect on the PCR result. Recently application of molecular tools has helped to resolve many of the taxonomic questions about the status of species and strains in the genus Echinococcus and establish the causative agent of hydatid disease in every country (6).

In most molecular studies of E. granulosus, commercial kits are used for the extraction of total genomic DNA (7-9). However, such kits can be expensive and are not always readily available in some countries. In this current study, we used a comparative assessment of four methods for extracting genomic DNA from protoscoleces of E. granulosus in order to select the best method to continue our studies on molecular epidemiology of $E$. granulosus.

\section{METHODS}

\section{Parasite specimens}

Several fresh fertile hydatid cysts of sheep and cows were collected from the slaughterhouse of Urmia and some other cities of the West Azerbaijan province. The samples were checked for the presence of protoscoleces microscopically for the assessment of fertility states. Protoscoleces were aspirated from the cysts and washed several times with saline solution until the supernatant looked clear. Then, the sediment was preserved in $75 \%$ ethanol until use.

\section{DNA extraction}

Protoscoleces sediments were selected to the DNA extraction stage. For each method, equal volumes of packed protoscoleces (about 30-50 $\mu \mathrm{l}$ ) were washed twice with sterile distilled water to remove ethanol. Then $300 \mu \mathrm{l}$ lysis buffer $(\mathrm{NaCl} 0.1 \mathrm{M}$, EDTA $0.01 \mathrm{M}$, Tris- $\mathrm{HCl} 0.1 \mathrm{M}$, SDS $1 \%$ ) was added to the sediment of each tube. The subsequent DNA extraction process was performed in two steps:
-Step one, which was used for disruption of cells and DNA release, was different for each method as follows:

1. Glass beads method: About $300 \mu$ l of $0.5 \mathrm{~mm}$ diameter glass beads was added to each tube and shaken vigorously using a dismembrator for $1 \mathrm{~min}$ in 900 shakes per minute.

2. Boiling method: The protoscoleces of each tube were incubated at $100^{\circ} \mathrm{C}$ for $10 \mathrm{~min}$.

3. Crushing method: Protoscoleces of each tube, inserted on the glass slide by sampler, were crushed with another glass slide for about $1 \mathrm{~min}$ and then the product was transported to the tube.

-Step two was similar for all methods:

$30 \mu \mathrm{g}$ of proteinase K (Fermentase, Lithuania) was added to each tube containing samples plus $300 \mu \mathrm{l}$ lysis buffer and incubated at $56^{\circ} \mathrm{C}$ for one hour. Then, $300 \mu \mathrm{l}$ phenolchloroform was added and centrifuged at $5000 \mathrm{rpm}$ for $5 \mathrm{~min}$. After removing the supernatant to a new tube, chloroform was added prior to shaking and spinning at $5000 \mathrm{rpm}$ for $5 \mathrm{~min}$. Subsequently an equal volume of iso-Propanol (Merck, Germany) and 0.1 volume sodium acetate (Merck, Germany) (3M, $\mathrm{pH}=5.2$ ) were added to the supernatant, and kept at $-20^{\circ} \mathrm{C}$ for 1 hour. Next, it was spun for 15 min in 14000 rpm and the sediment was rinsed by $300 \mu \mathrm{l} 70 \%$ ethanol. After spinning $5 \mathrm{~min}$ at $5000 \mathrm{rpm}$ and removing ethanol, the pellet was dissolved in $50 \mu \mathrm{l}$ deionized water, and stored at $-20^{\circ} \mathrm{C}$.

\section{Commercial kit method:}

The hydatid cyst protoscoleces were washed under sterile conditions using a commercial DNA purification kit (CinnaPure DNA, Cinnagen, Iran ) in accordance with the manufacturer's instructions and stored at $-20^{\circ} \mathrm{C}$ until use.

The extracted DNAs of each method were loaded on $1.3 \%$ TBE (Tris 0.09M-Borate 0.09M-EDTA 0.02M) agarose gel (Cinnagen, Iran), respectively. Electrophoresis was carried out for 1 hour at $80 \mathrm{~V}$. Then the gels were stained in $100 \mu \mathrm{g} / \mathrm{L}$ ethidium bromide solution (Cinnagen, Iran) for 25 minutes. The bands were visualized in UV transilluminator (Gel documenter) and digitally photographed.

\section{RESULTS}

Overall, 31 DNA samples, were extracted from 5 to 8 hydatid cyst isolates by four methods. After choosing the best method of DNA extraction method, we extracted other samples using the selected method.

Figures 1-4 shows the agarose gel electrophoresis of extracted DNA from samples. As is seen all samples, except the commercial DNA extraction kit, have a distinct band for samples. However, a visible smear was observed in DNA electrophoresis for all methods. The size of DNA was apparently equal in every extraction method. According to the images, it seems that the Glass beads method gives quantitatively better yields of DNA.

\section{DISCUSSION}

There are several methods for DNA extraction of fungi and bacteria and also worms and protozoa, however a few methods are 


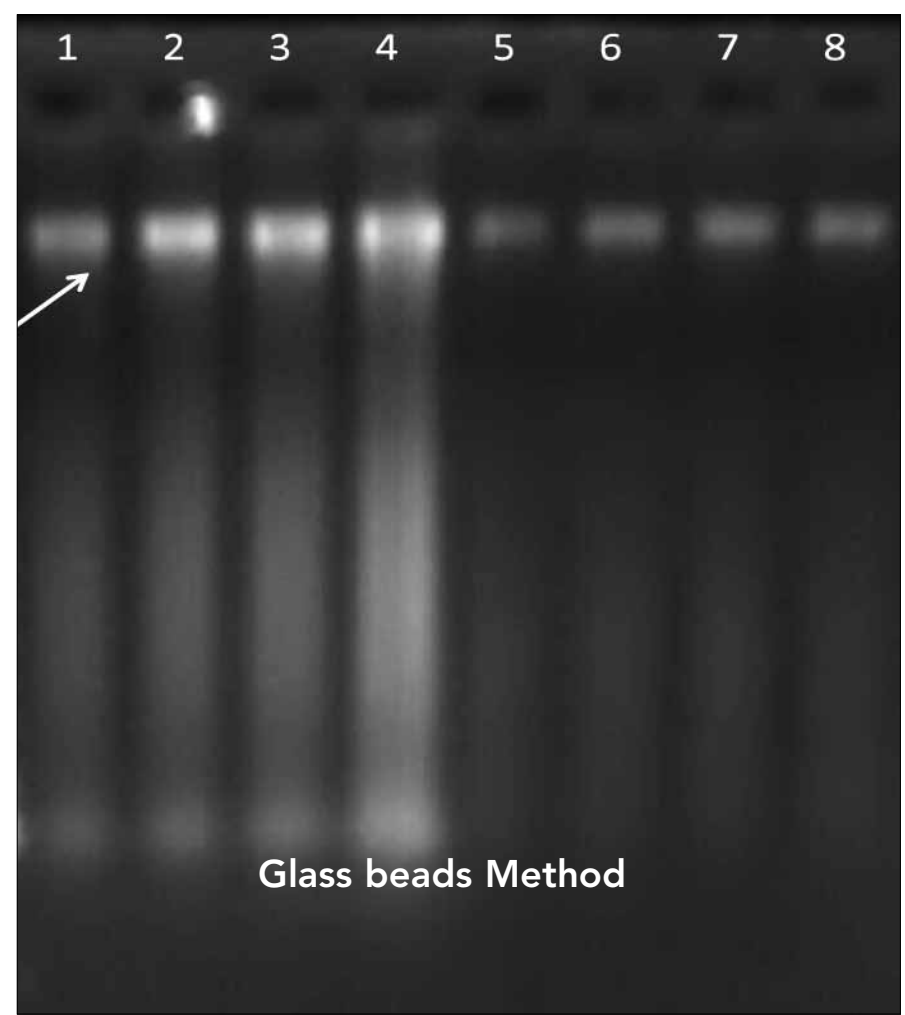

Figure 1. Agarose gel electrophoresis of extracted DNA from 1-8 hydatid cysts isolates with the glass beads method

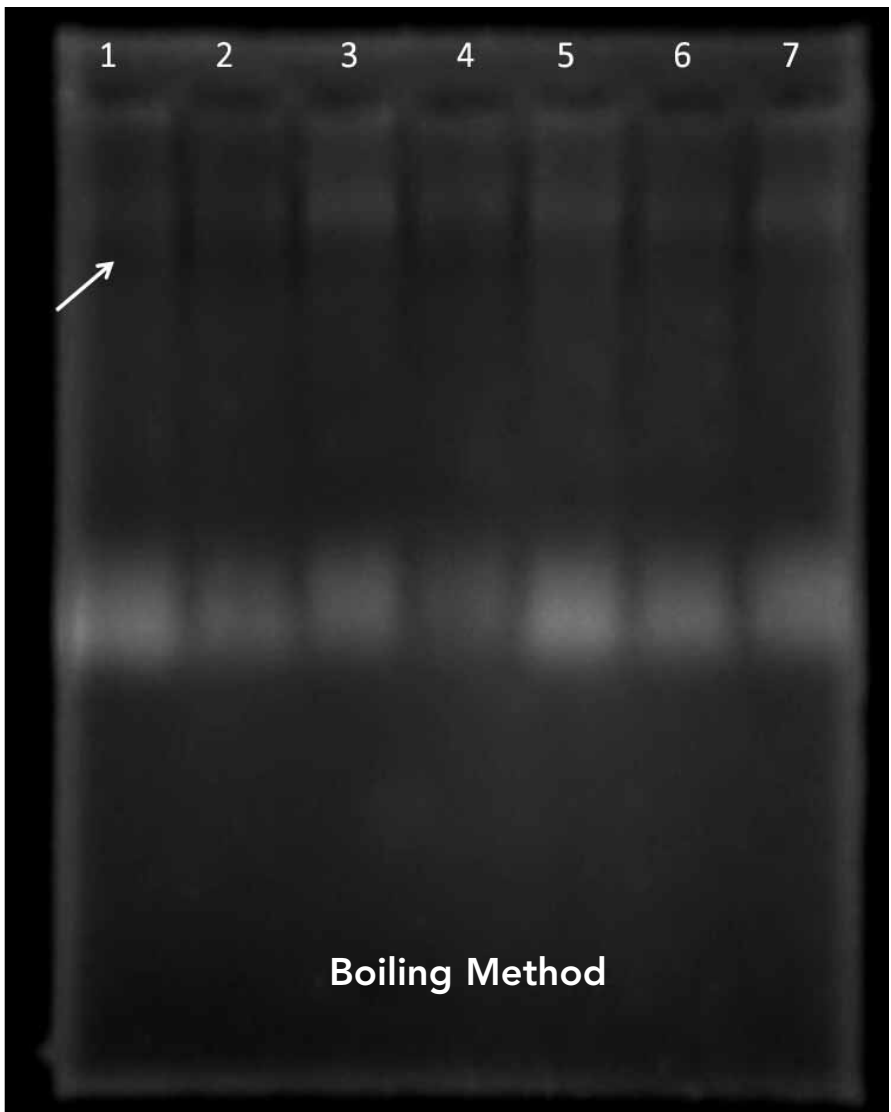

Figure 2. Agarose gel electrophoresis of extracted DNA from 1-7 hydatid cysts isolates with the boiling method

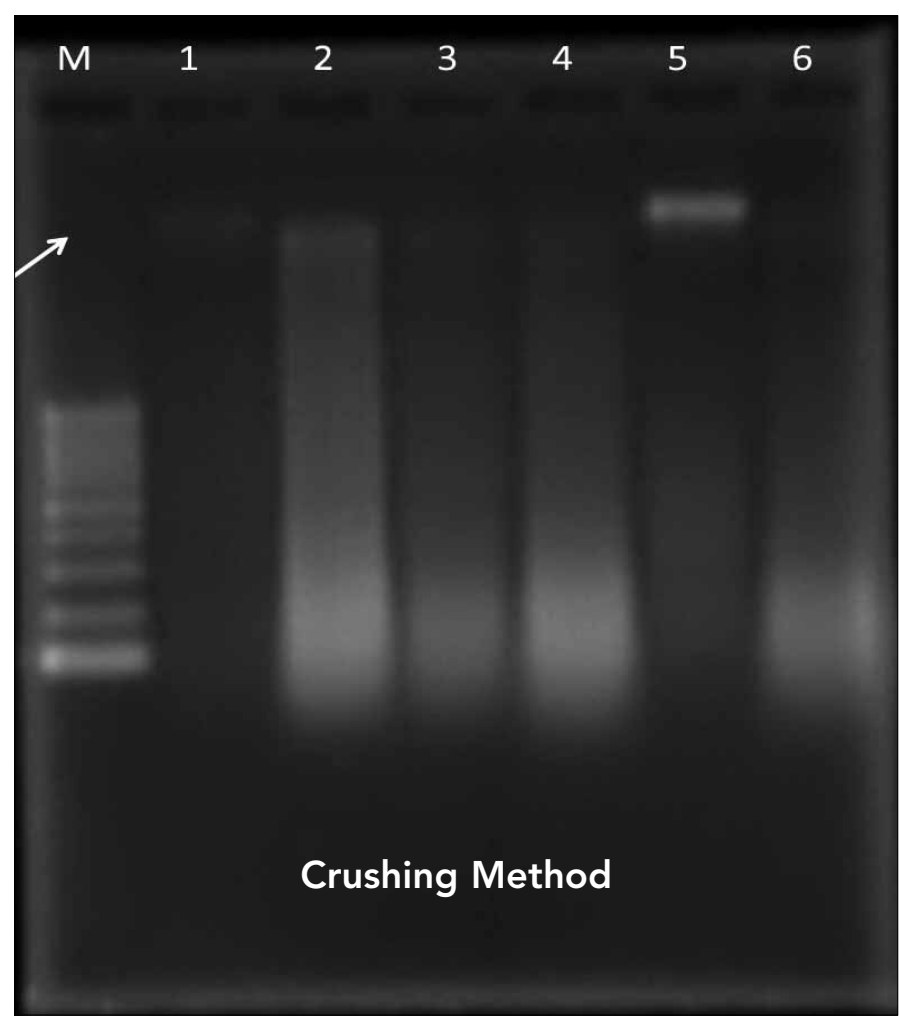

Figure 3. Agarose gel electrophoresis of extracted DNA from 1-6 hydatid cysts isolates with the crushing method

$\begin{array}{lllllll}\text { NC } & P C & 1 & 2 & 3 & 4 & 5\end{array}$

Figure 4. Agarose gel electrophoresis of extracted DNA from 1-5 hydatid cysts isolates with the Commercial Kit method 
mentioned and compared for protoscoleces of E. granulosus. For example Apfalter et al. (10) by comparing extracting DNA from Chlamydia pneumonia, used some methods such as Proteinase $\mathrm{K}$ digestion, $\mathrm{PClc}$, ethanol precipitation and different commercial kits and reported various results.

In another study, Key et al. (11) compared three methods of DNA extraction in Mycobacterium tuberculosis including a Commercial DNA extraction technique-ZR soil microbe DNA kit, traditional salt-ethanol precipitation and column filtration. Except for the last method, they achieved acceptable results.

In most molecular studies of E. granulosus, commercial DNA extraction kits, such as High Pure PCR Preparation Kit (Roche, Germany) (7, 8, 12), QlAamp DNA mini Kit (Qiagen, Germany) (9), Wizard Genomic DNA Purification Kit (13), Q-bio Gene Kit (USA) (14) have been used for extracting DNA. A few studies have used liquid nitrogen for the crushing of protoscoleces $(15,16)$.

Commercial kits have a proper application when a large numbers of samples containing low numbers of organisms are processed. Although the application of kits is quick, and easy for obtaining nucleic acids, they can be expensive and not readily available in some countries. Application of liquid nitrogen seems simple but laborious. Moreover, liquid nitrogen can be expensive to purchase and keep in suitable condition (6).

Rostami Nejad et al. (17) in a study named Evaluation of four DNA extraction methods for the detection of $E$. granulosus genotype 1, Used Phenol-chloroform, Modified Cinnagen extraction kit, Tissue Extraction Kit and Modified phenol-chloroform methods to extract DNA of E. granulosus The result of his study showed that the quality of extracted DNA using the modified Cinnagen extraction kit and modified phenol-chloroform are very high and gave identical results after RCR reaction using $12 \mathrm{~S}$ rRNA gene.

Sharbatkhori et al. (6), in a first study of comparison of simple methods for DNA extraction from $E$. granulosus protoscoleces, used five different methods involving the use of glass beads, mechanical grinder, freeze-thaw, boiling and crushing. For all DNA samples extracted, one PCR assay based on amplifying rDNA ITS1 region was performed and amplicons resolved on $1.5 \%$ agarose gels. The methods were compared regarding DNA and PCR bands, time and cost effectiveness and laboriousness. The target DNA was successfully amplified from all samples using all methods producing an expected band size. All methods showed some advantages and disadvantages in PCR gels. The boiling method, which was the most time and cost effective method, achieved the thickest bands in the PCR following grinder, crushing, freeze-thaw and glass beads.

Our aim was to find a quick, easy to perform, cost effective and practical DNA extraction method for application in laboratories which are not supported with expensive commercial kits. In all methods, DNA were extracted from protoscoleces and then purified by phenol chloroform.

Extraction was followed by alcohol precipitation. The glass beads method was easy and quicker than others, and also in this method we had a greater yield of DNA,. The boiling method was alsoquick however the results were not acceptable. Anther method was crushing protoscoleces between two glass slides, this crushing method did not show the high quality PCR bands except for one sample and yielded the most amount of DNA smear compared with other methods.

The commercial kit method was too long a process and an expensive method without any band of DNA.

Overall, all methods showed some advantages and disadvantages but considering the different aspects of suitability for a DNA extraction method such as time consuming, cost effectiveness and simplicity, the glass beads and boiling methods were the most suitable methods considering their simplicity and quickness. These methods can be used for future molecular studies of E. granulosus.

\section{Conflict of Interest}

No conflict of interest was declared by the authors.

\section{REFERENCES}

1. Parsa F, Haghpanah B, Pestechian N, Salehi M. Molecular epidemiology of Echinococcus granulosus strains in domestic herbivores of Lorestan, Iran. Jundishapur J Microbiol 2011; 4: 123-30.

2. Sadjjadi SM. Present situation of echinococcosis in the Middle East and Arabic North Africa. Parasitol Int 2006; 55: 197-202. [CrossRef]

3. Dinkel A, Njoroge EM, Zimmermann A, Wälz M, Zeyhle E, Elmahdi IE, et al. A PCR systems for detection of species and genotypes of the Echinococcus granulosus complex, with reference to the epidemiological situation in eastern Africa. Int J Parasitol 2004; 34: 645-53. [CrossRef]

4. Eckert J, Schantz PM, Gasser RB, Torgerson PR, Bessonov AS, Movsessian SO. Geographic distribution and prevalence. In: Eckert J, Gemmell MA, Meslin FX, Pawlowski ZS (eds) WHO/OIE Manual on Echinococcosis in Human and animals: A public health problem of global concern, Paris: World Organisation for Animal Health 2001; 100-42.

5. Thompson RCA, Mc Manus DP. Aetiology: parasites and life cycles. In: Eckert J, Gemmell MA, Meslin FX, Pawlowski ZS (eds) WHO/OIE Manual on Echinococcosis in Human and animals: A public health problem of global concern, Paris: World Organisation for Animal Health 2001; 1-19.

6. Sharbatkhori M, Kia EB, Fasihi Harandi M, Jalalizand N, Zahabiun F, Mirhendi H. Comparison of Five Simple Methods for DNA Extraction from Echinococcus granulosus Protoscoleces for PCR Amplification of Ribosomal DNA. Iranian J Parasitol 2009; 4: 54-60.

7. Maillard S, Benchikh-Elfegoun M, Knapp J, Bart J, Koskei P, Gottstein $B$, et al. Taxonomic position and geographical distribution of the common sheep G1 and camel G6 strains of Echinococcus granulosus in three African countries. Parasitol Res 2007; 100: 495-503. [CrossRef]

8. Bart J, Morariu S, Knapp J, llie M, Pitulescu M, Anghel A, Cosoroabal, Piarroux R. Genetic typing of Echinococcus granulosus in Romania. Parasitol Res 2006; 98:130-7. [CrossRef]

9. Zhang LH, Chai JJ, Jiao W, Osman Y, McManus DP. Mitochondrial genomic markers confirm the presence of the camel strain (G6 genotype) of Echinococcus granulosus in north-western China. Parasitology 1998; 116: 29-33. [CrossRef]

10. Apfalter P, Blasi F, Boman J, Gaydos CA, Kundi M, Maass M, et al. Multicenter Comparison Trial of DNA Extraction Methods and PCR Assays for Detection of Chlamydia pneumonia in Endarterectomy Specimens. J Clin Microbiol 2001; 39: 519-24. [CrossRef]

11. Kay MK, Linke L, Triantis J, Salman MD, Larsen RS. Evaluation of DNA extraction techniques for detecting Mycobacterium tuberculosis complex organisms in Asian elephant trunk wash samples. Clin Microbiol 2011; 49: 618-23. [CrossRef] 
12. Bardonnet K, Piarroux R, Dia L, Schneegans F, Beurdeley A, Godot V, et al. Combined eco-epidemiological and molecular biology approaches to assess Echinococcus granulosus transmission to humans in Mauritania: occurrence of the camel strain and human cystic echinococcosis. Trans R Soc Trop Med Hyg 2002; 96: 383-6. [CrossRef]

13. Busi M, Snábel V, Varcasia A, Garippa G, Perrone V, De Liberato C, et al. Genetic variation within and between $\mathrm{G} 1$ and $\mathrm{G} 3$ genotypes of Echinococcus granulosus in Italy revealed by multilocus DNA sequencing. Vet Parasitol 2007; 150: 75-83. [CrossRef]

14. Bhattacharya D, Bera AK, Bera BC, Maity A, Das SK. Genotypic characterization of Indian cattle, buffalo and sheep isolates of Echinococcus granulosus. Vet Parasitol 2007; 143: 371-4. [CrossRef]
15. Snabel V, D'Amelio S, Mathiopoulos K, Turcekova L, Dubinsky P. Molecular evidence for the presence of a G7 genotype of Echinococcus granulosus in Slovakia. J Helminthol 2000; 74: 177-81.

16. Kamenetzky L, Canova SG, Guarnera EA, Rosenzvit MC. Echinococcus granulosus: DNA extraction from germinal layers allows strain determination in fertile and nonfertile hydatid cysts. Exp Parasitol 2000; 95: 122-7. [CrossRef]

17. Rostami Nejad M, Roshani M, Lahmi F, Nazemalhosseini Mojarad E. Evaluation of four DNA extraction methods for the detection of Echinococcus granulosus genotype 1. Gastroenterology and Hepatology From Bed to Bench 2011; 4: 91-4. 